\title{
Developing an Independent Anti-Racist Model for Asylum Rights Organizing in England
}

\author{
Abstract \\ Since the mid 1990s third sector professionals and organizations have \\ come under increasing pressure to help enforce restrictive and punitive \\ policies toward refugees and asylum seekers. This paper presents one \\ response, using an empirical case study to develop an 'Independent \\ Anti-Racist Model' for asylum rights organising. This combines data from \\ a three-year study comparing four organizations in a major city in \\ England and reflections on the author's experience as a member of the \\ case study organization, contextualized in the literature. The paper \\ identifies a related set of features distinguishing this model from other \\ types of organization and the conditions making it possible and \\ concludes that it offers wider lessons for work with groups in a \\ conflictual relationship with the state.
}

\section{Keywords}

refugees; community mobilizing; community development; social movements; collectivism; internationalism

\section{Acknowledgements}

Thanks are due the participants in the research that informs this paper, and to the ERS referees and other colleagues who commented on earlier drafts. Responsibility for any shortcomings is mine. 


\section{Introduction}

This paper responds to critiques suggesting that where British state policies and practices jeopardise the interests of refugees, as I call all those who seek asylum ${ }^{1}$, many third sector professionals have limited ability to intervene, and in some cases are complicit with the state's agenda (Hayes 2005; Briskman and Cemlyn 2005; Griffiths et al. 2005). This paper uses a case study of an alternative approach that overcame these limitations, to develop an 'Independent Anti-Racist Model' (IARM) for asylum rights organising. The presentation of a conceptual model, understood as a 'simplified framework of key variables', follows the use of models by community practitioners to 'get a "handle" on the situations, processes and systems they have to deal with' (Henderson 2007 , p. 10), supporting generalization to other contexts.

The paper begins by using a discussion of the literature to consider the conditions facing refugees and those working with them. This is followed by an outline of the research that informs the model. The paper then considers the IARM's main features, and concludes by analysing the conditions that made this model viable in a particular time and place and considering its transferability.

\section{The 'right to asylum': theory and practice ${ }^{2}$}

Britain is a signatory to the 1951 UN Convention on Refugees, representing a commitment to rights of entry and settlement for foreign nationals on the basis of a universalist claim to safety from persecution (Kundnani 2007, p. 24). This contradicts the priority given to private wealth, or in its absence labour market demand, as a basis for settlement within neoliberal policies guiding British governments since the 1990s (Chinweizu and Jameson 2008; Morris 2007, p. 46). Asylum claims are particularly problematic where the British state is directly or indirectly involved in situations creating refugees, of which the wars in Iraq and Afghanistan are only the most obvious (Schuster 2002; Kundnani 2007; Vickers 2012). These contradictions are reflected in a decision-making process for asylum claims that is fair in theory but in practice weighted heavily against refugees (BID 2009). In the first quarter of 2010, 76 per cent of asylum applications were refused, in a context where 93 per cent of applications for other forms of settlement were granted (Home Office 2010). 
Since the late 1990s, the British government has introduced a series of measures making refugees' lives increasingly difficult. Between 1997 and 2010 immigration detention facilities expanded to a capacity of over 3,000, among the largest in Europe, with the most common category of detainees in 2010 people who had sought asylum (Silverman 2011). Outside detention, refugees without status must sign regularly at Immigration Reporting Centres or police stations, increasing a sense of criminalization. In 1999 a 'dispersal' programme began, further isolating refugees by moving them to another city often just when they were starting to form new relationships (Hynes 2009). The main justification was that too many refugees in one place would fuel racism, implicitly blaming ethnic minorities themselves for the racism they face (Kundnani 2007, pp. 81-3). Access to many statutory welfare services was removed, to be replaced by the National Asylum Support Service (NASS), with payments for destitute refugees without status 30 per cent below unemployment benefits for British citizens and initially given in the form of stigmatising vouchers only redeemable for food (Sales 2002). In 2002 a new law prohibited most refugees without status from taking paid work, reinforcing dependency on state benefits.

Alongside dispersal, voluntary sector organizations specifically targeting refugees grew in number and geographical spread (WLRI 2005). In many dispersal areas little preparatory work was done, forcing voluntary sector organizations, churches and RCOs (Refugee Community Organizations) to respond quickly (Hewitt 2002, p. 7). This created pressure toward a narrow focus on service provision and partnerships with the local state. Briskman and Cemlyn (2005) conducted interviews with asylum teams and voluntary agencies, finding:

a mixed picture among those with government funding between maintaining independence and advocacy on behalf of asylumseekers' rights, and becoming enmeshed in managing an unsatisfactory situation. (p. 719)

While many professionals were, and are, driven by personal and professional values to support refugees, they increasingly found themselves called on to act as a second line of immigration control, policing access to resources (Hayes 2005, pp. 191-2; Humphries 2004). Even among RCOs, overtly critical voices were often sidelined as organizations were drawn into the requirements of funding regimes 
reliant on the state (Griffiths et al. 2005, pp. 22-3). This is the context which led CAMP's founders to believe a new organization was necessary, one free to defend refugees' interests even to the point of open confrontation with the state, and that leads me to conclude the model carries wider relevance.

\section{Case study background and methodology}

This paper draws on a study between 2007 and 2010 funded by the Economic and Social Research Council in a British city receiving refugees without status under the dispersal system. Many refugees were housed in working class areas with few ethnic minority people already resident, and some in areas scheduled for demolition and boarded up, where break-ins, fires and serious racial attacks were common.

The study investigated relationships between experiences, consciousness and voluntary activity among refugees and included a cross-case analysis of four third sector organizations that involved refugees as members/volunteers. Refugees in Britain are to an extent a 'hidden population', which limits the utility of purely statistical methods and increases the relevance of case studies (Esterhuizen 2004, p. 10). The sample was constructed to include organizations founded in 2006 or earlier and still in existence in 2008, with a range of relationships to the state and covering a range of activities. Heterogeneity of cases created possibilities for replication and contrast (Yin 2003, pp. 46-53). Organizations are indicated by anonymized acronyms: VOL, a voluntary sector project delivering contracts for the Home Office; COM, a community advice and signposting project established by refugees; CHUR, a church-based project delivering signposting, advice and hardship support; and CAMP, an asylum rights campaign group that forms the basis for the IARM. Data included transcripts of twenty-four indepth semi-structured interviews and two focus groups involving eighteen refugees, contextualized through background interviews with five managers and twelve other professionals. The direct quotations in this paper are from interviews with six members of CAMP who were refugees, most without status, interviewed between 2008 and 2010. Some were sought out because they played a leading role in the organization, others volunteered when I announced my research at one of CAMP's monthly General Meetings. The refugees I interviewed in 
CAMP were all women, from six African countries, and had arrived in the city between 2000 and 2008. I also draw on a book chapter (Banks 2007), which discusses CAMP under the pseudonym ASN, using interview and focus group data I was commissioned to gather in 2006 before I began my own study. Banks uses CAMP to illustrate aspects of the Critical Community Practice (CCP) model discussed below.

In addition to these sources, the paper reflects on my experiences as a CAMP member between 2006 and 2012. I take a committed approach, supporting refugees' struggles to remain in Britain and meet their needs. I also took positions within CAMP's sometimes fiercely contested debates. My 'insider-outsider' position offers insights otherwise unavailable, and calls for a reflexive approach. My work is informed by a Marxist understanding of the relationship between social divisions and ideas. Marxism demonstrates the ideological role of liberal claims to 'objectivity', in representing the ideas arising from one set of class interests as an absolute truth. I argue there are different kinds of knowledge beneficial or dangerous to the interests of different classes, whose members possess different capacities to propagate their kind of knowledge (Marx and Engels [1845] 1991, p. 64). I make no claims to objectivity, but aim to make my subjective position clear to enable the reader to engage critically with the account I present. By articulating a perspective of radical political action often missing from discussions of the range of activity in the third sector, I aim to contribute to a fuller understanding of the world, as part of what Sandra Harding calls 'strong objectivity' (Hirsh and Olson 1995).

\section{Findings and Discussion: Distinctive features of the model}

CAMP was established following a regional meeting organized by a national anti-deportation network in autumn 2005. At this meeting, a member of a communist organization proposed establishing a local asylum rights network. This brought together a small group of individuals who organized a series of meetings, leading to the formal founding of CAMP in early 2006. Between 2006 and 2010 a combination of features distinguished CAMP from other contemporary organizations, providing a basis for conceptualizing an Independent Anti-Racist Model for asylum rights organising (IARM). Figure 1 outlines the dimensions of the model, which will be explored below. These emerged through a cross-case comparison of the four organizations in my study, as key points of 
difference. The development of a model is not intended to imply that CAMP was unique or unprecedented, but rather to: facilitate comparisons within wider histories of political community organising (although such comparisons are beyond the scope of this paper); demonstrate the utility and challenges of such approaches in the contemporary UK asylum context, where they are largely absent; explain the relationship between objective and subjective factors that enabled CAMP to develop, to inform transferability to other contexts. The dimensions of the IARM broadly map onto those in the Critical Community Practice model (CCP) (Butcher et al. 2007): the IARM's 'Values' relate to the CCP's 'critical theorising'; the IARM's basis for 'Membership' in anti-racism represents a form of the CCP's 'critical consciousness'; the IARM's focus on 'Structure' relates to the CCP's facilitation of 'critical reflection'; and the IARM's 'Action' corresponds to the CCP's 'critical action'. An additional fifth dimension in the IARM, 'Resources', reflects the higher priority attached to the material basis of social relations in this model compared to the CCP. The two models are not identical, and neither is the IARM a variant of the CCP simply adapted to the asylum rights context, but they are close enough that comparison improves clarity. 
Figure 1: Dimensions of the IARM

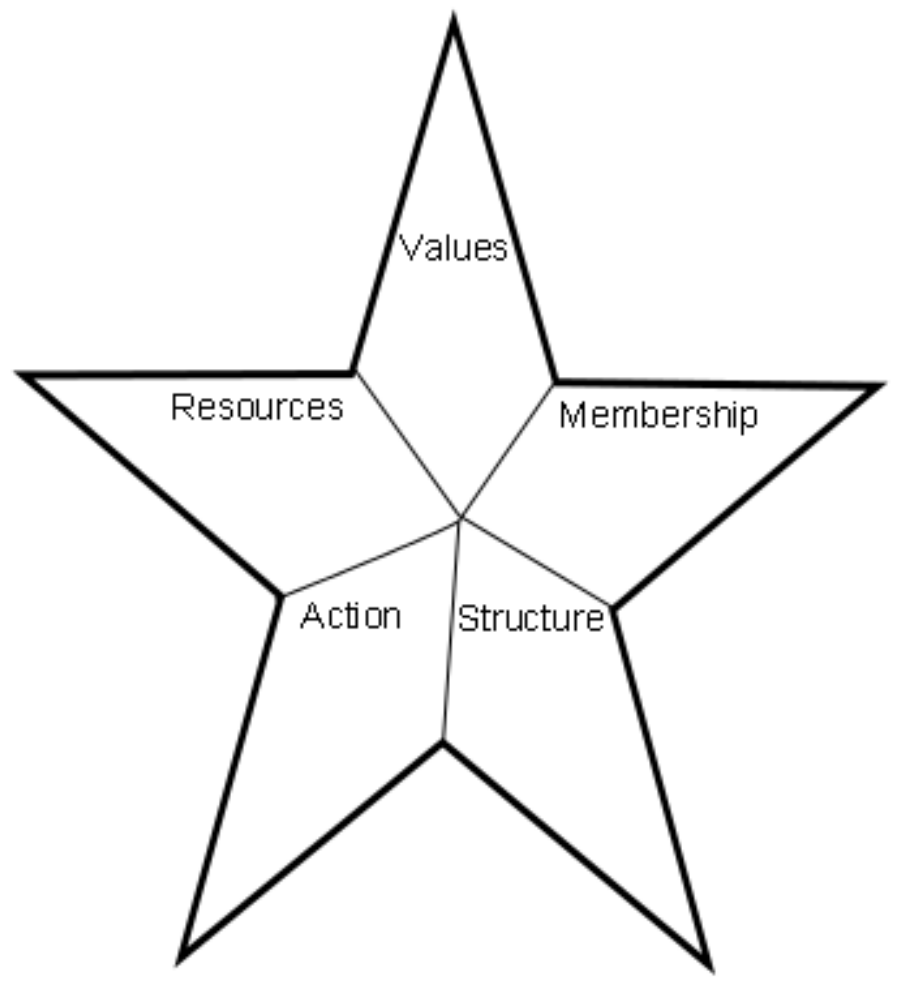

Values: Internationalism and collectivism

Although not discussed explicitly within CAMP, the theoretical assumptions of the CCP can be seen implicitly in the organization's work, including: the importance of human sociality; the potential for purposive collective action; the social construction of society and social institutions and therefore their capacity for change; and the potential for all members of society to participate in decision-making (Butcher 2007, pp. 53-6). However, CAMP went beyond these generalizations to also address specific structures and processes shaping refugees' experiences of flight and settlement, and the implications of people's and institutions' positions within the international capitalist system.

Internationalism underpinned CAMP's work, linking the British government's treatment of refugees with its foreign policy interests. This is expressed in the following excerpts from a press release in 2008:

Husband and wife ... have already lost all trace of three of their children ... as a result of the conflict in their home country of Nigeria. Now the family are faced with deportation ... with their last remaining daughter ... Nigerian armed groups such as the 
Movement for the Emancipation of the Niger Delta (MEND) have been battling western oil companies and the British- and USbacked government for control of the country's resources ... [CAMP] opposes the racist and degrading treatment of this and every asylum seeking family by the current Labour Government. While families continue to be dragged from their homes, into detention centres and onto planes against their will then we will continue to oppose and expose the shameful actions of the Home Office on the streets and in the media

Such connections, between racism and imperialism, have a long history in anti-racist critiques that point to structural as well as cultural factors in racialized inequalities (e.g. Ahmad and Atkin 1996; Craig 2007). Yet they have often been missing, particularly since the 1990s in Britain, from anti-deportation campaigns, RCOs and the wider refugee sector. These ideas were introduced by sections of CAMP's membership including: communists; refugees with backgrounds in movements opposing governments that were close to the British government, such as those of the DRC and Cameroon; refugees who had experienced direct military intervention by Britain, in countries such as Iraq and Afghanistan; and refugees who had been part of national liberation struggles, for example Kurds from Turkey.

A second principle underpinning CAMP's work was the identification of individual interests with a wider collective, as one member explained:

Everyone there in CAMP is there for everybody, if anybody is snatched, we stand up for each other ... a kind of solidarity ... that's what I like about it

Public actions focusing on individuals were generally limited to 'emergency' situations of impending deportation. A focus group in 2006 found 'some areas of disagreement and debate over the balance of the work of the group between campaigning work (including demonstrations) and support for individuals (legal and moral support, as well as material support in terms of finance, childcare and accommodation)' (Banks 2007, p. 82). The relationship of the individual to the collective was a recurring issue of discussion within CAMP, but was not necessarily a contradiction. Some CAMP members I interviewed described how public defence of collective interests, 
embodied in opposition to all deportations, combined with close attention to individuals' experiences, perspectives and abilities:

[Another organization] are more strategic ... if something happens to an asylum seeker or a black person on the street, there is nothing that [the organization] can do for that particular case, they can only go to the person and say you have to be more careful ... I think CAMP is more personal, [in] the sense that we have the power to go to the person ... and people are able to come and talk to us

Another member described the importance of 'meet[ing] people in [the] same situation ... when you share, you feel a little bit of relief, instead of just staying at home and keeping everything inside'. As Takhar (2011, p. 347) puts it, "It is the identification with a collective identity which allows for the personal empowerment of both parties in this social relationship'. In CAMP, a close relationship between the personal and the political was actively nurtured through an open format in meetings, sufficiently flexible to enable individuals to bring personal issues to the group, to become part of a collective process through discussion linked to action. Such practices can transform individual day-to-day experiences of oppression into new forms of consciousness, which build solidarity and stimulate resistance (Hill Collins 1990).

Internationalism and identification with collective interests distinguish CAMP from the other organizations in my study, who largely limited their criticisms of the British state to its actions within Britain, and approached refugees as individualized 'service users' or 'clients'. In this respect, CAMP is also distinct from many other anti-deportation campaigns. One of the most prominent national anti-deportation networks in Britain in recent years has avoided mention of Britain's involvement in countries refugees flee, on the basis that this might undermine support from British politicians (personal correspondence). It has also focused overwhelmingly on individual cases. In CAMP values of internationalism and collectivism provided an effective basis for mobilizations over a sustained period, by people from many different countries, which helped to stop the deportation of a number of individuals, as well as contributing to longer term political pressure and public awareness. The priority given to opposing all deportations impeded any section of CAMP becoming complicit in defining 'acceptable' and 'unacceptable' migrants, as occurred in France in the 
1990s as a result of human rights associations' focus on the regularization of individuals' immigration status (Nicholls 2011, pp. 1417).

\section{Membership: An anti-racist alliance}

CAMP operated as a political alliance between groups and individuals committed to defending refugees, in the context of the stark contradictions outlined above. This was expressed through a politics of anti-racism, which Lentin and Titley $(2011$, p. 70$)$ argue is distinguished from more purely theoretical 'post-racial' rejections of racial ideas by practices of 'standing up to those conditions' of racialized 'being or living'. When white people in CAMP heard first-hand about refugees' treatment by the British state, it raised their consciousness of the contradictions within the 'post-racial' claims of state-sponsored forms of multiculturalism. This is indicative of the 'potential power and mobilizing effects' of anti-racism, capable of drawing together black ${ }^{3}$ and white people in struggle, particularly where connections are identified between racism and other forms of oppression under capitalism (Penketh 2000, pp. 27-8). Pointing out such connections was a major focus for communists in CAMP.

CAMP's anti-racist response to the state's treatment of refugees brought together: refugees without status (the majority of the active membership between 2006 and 2010); refugees with status; experienced non-refugee activists with a range of communist, anarchist and social democratic perspectives and various ethnic identities; and other non-refugees who became politicized through contact with asylum rights issues. This diversity of backgrounds provided CAMP with lessons from previous social movements, from many different countries. Antiracism formed a dynamic basis for alliances combining the resources and local knowledge of longer-resident activists with the mobilizing ability of migrant communities based on strong within-group ties, a combination which has been a recurring feature of migrant rights movements in many countries (Nicholls 2011, p. 3). This created collective strength, on an explicitly political basis, that enabled CAMP to avoid the kind of cooption effected through identity politics' incorporation into a de-politicized, state-sponsored 'politics of diversity'. This has involved expectations that racialized minority people define themselves as easily identifiable groups in terms of dominant discourses (Shukra 
1995, pp. 13-14) and has wielded culture as a political tool, 'invoked to solve problems that previously were the province of economics and politics' (Yúdice 2003, p. 23).

CAMP's heterogeneous membership also created tensions. Members had different understandings of the causes of problems the organization was trying to address, which led to different strategies. In contrast to anti-fascist alliances, whose focus on groups and individuals at the margins of society often blurs political differences (Lentin 2004, p. 204), CAMP's focus on the racism of the British state, at the centre of British society, sharpened differences. While communist members viewed the struggle for asylum rights as ultimately unwinnable without a wider struggle for revolutionary change, for some other members 'their concern [was] essentially reformist - to be able to impress upon the British authorities the ways in which the system is not working for them, and seeking improvements in childcare, education, housing and the legal processes' (Banks 2007, p. 87). These political differences were complex and shifting, and cut across categories of refugees and nonrefugees. For example, in 2007 a motion was brought to a CAMP General Meeting by a loose grouping of social democrats and anarchists and defeated, which would have excluded communists (some of whom were refugees) from CAMP on the basis of their collective organization. This was seen by communist members as part of a wider effort to depoliticize CAMP. Negotiation of these differences was facilitated by democratic structures outlined below, and anti-racism formed an important unifying factor. As with the organization in Bailey's (2012) research, members' 'commitment to the wider cause, as well as their strong emotional ties, support[ed] their participation in shared activities beyond difference and occasional tensions' ( $p$.861).

Among the other organizations in my study: VOL shared the involvement of refugees and non-refugees at all levels; COM was run by refugees, with the exception of occasional student placements; CHUR employed white British, paid professionals and a small number of unpaid refugees, mostly doing translation work, as well as British volunteers. CAMP's character as an anti-racist alliance involving significant proportions of refugees and non-refugees distinguished it from types including: community organising, 'often limited by separate organising' among black and white people (Ledwith and Asgill 2000, p. 294); organization around an immigration category or national origin (for 
example the African women's group in Bailey 2012); solidarity organizations supporting refugees without involving them as core members (for example the 'rights organizations' in Nicholls 2011); or approaches which explicitly place people in different organizations by immigration status (for example the separate organizations for migrants and supporters in Anderson 2010).

Structure: Participatory democracy

CAMP organized in a way intended to maximize participation in decision-making by the whole membership. Structures shifted over time, in response to the changing context, size of membership, and reflection and discussion among members. In the initial period, open organising meetings took place every two weeks, with anyone attending entitled to vote. By the time the organization approached its first anniversary, there was widespread agreement that these meetings were too large to complete tasks effectively, and also too frequent for many members to maintain consistent attendance. In response to this, the format was changed to weekly organising meetings and a monthly General Meeting, with the latter retaining the power to make strategic decisions. At various times, working groups were created to enable members to become more involved in areas of particular interest.

Although this open organising structure allowed a high degree of participation, it presented difficulties ensuring tasks were completed. In many RCOs, the pressure on refugees as clients, volunteers and staff can lead to organizational instability (Evelyn Oldfield Unit 2004, p. 7). Similarly for CAMP, the insecure personal circumstances of many members (often including non-refugees) both made an open and fluid structure important, enabling members to contribute to decisions when they were able and to withdraw when they were not, and created problems, as the individuals attending meetings could change significantly from week to week and month to month. Nationality-based community dynamics added to this; in the first year of CAMP's existence, first Iranian, then Congolese, then Eritrean, then Kurdish, refugees participated in CAMP in large numbers but at different times, often with a few individuals continuing longer-term involvement once the main 'community' mobilization had subsided. CAMP attempted to respond to these challenges through the election of a committee, yet in my experience, the organization was at its most vibrant and confident 
when the majority of the organising took place in open meetings, including tasks taken on by ordinary members.

CAMP's structure aimed to facilitate collective deliberation as part of a process of mutual empowerment. In discussion of the CCP, Butcher (2007, pp. 72-5) asks how reflection might be fostered at a collective level, and calls for 'systems thinking', building a shared vision, team reflection, and making explicit the models members are using. As Ledwith and Asgill (2000, p. 292) point out in their reflections on alliances between black and white women, the socio-political context of capitalism directly militates against the fulfilment of a shared vision of 'community solidarity and trust' across racialized difference, and struggling to achieve this therefore requires ongoing reflection about 'our cultures, our histories, our differently positioned power and identities'. Although the degree to which this was achieved varied widely among CAMP's diverse and shifting membership, the weekly meetings played an important role in sharing ideas and perspectives as part of a reflective process, with broad political questions discussed alongside practical issues. Members I interviewed reported empowering democratic processes of open debate reaching agreement through exhaustive discussion:

Sometimes everybody [has] news, everybody [has an] opinion ... I like it because everybody [is] free to talk, say [what] you think to develop ... our community ... they can look at your opinion, take this one, or leave this one, [decide on the] best one, help the group to grow

This level of participation, and the sense of control it cultivated, constituted a powerful influence towards not only collective identity, but also a degree of collective agency.

The role of refugees in the leadership of CAMP was complex and uneven. Within meetings refugees were as active as non-refugees in deciding on strategy and tactics, and their arguments carried the additional weight of direct experience of the asylum system. Some became 'organic intellectuals' (Gramsci [1929-1935] 1982, pp. 204-5), maintaining a connection between CAMP and wider refugee communities and developing others' understanding and confidence. Of the five Chairs of CAMP between 2006 and 2010, three were refugees without status (the other two were black people who had grown up in the city where CAMP was based), and refugees were prominent on CAMP's 
many street protests, including addressing the public using megaphones and personal address systems. Yet there was also a tendency in certain situations for non-refugees to act as 'representational brokers' (a term used by Nicholls 2011, p. 12), disproportionately visible in CAMP's contact with the press, government officials, and police. Contributory factors included non-refugees' longer experience of British institutions and some refugees' fears that if authorities saw them as leading the organization, they may be targeted them for deportation ${ }^{4}$. It may, therefore, be understandable, but nevertheless raises questions about self-representation of refugee members. Additionally, a refugee who served as Chair of CAMP for eighteen months reported frustration that some members spoke privately about things they thought CAMP should do differently, but would not raise them in a meeting:

For me [the challenge is] how to get asylum seekers more involved, and to also know that they have some power ... people talk to me ... if they want to complain about something, [but] they get discouraged very easily ... nobody can guess what asylum seekers want, unless they are there and they [say what they want]

This illustrates the complex power relations within such diverse alliances. This calls for democratic structures, an ongoing effort to overcome obstacles limiting members' involvement, and an active struggle against the influence, of oppressive structures and processes within wider society, on relationships within the organization.

CAMP's structure contrasted with the other organizations in my study, which in common with much of the third sector used an Annual General Meeting to elect some form of management committee that led the organization for the rest of the year, with paid workers in charge of day-to-day operations. This is the format required by most funders, and so is closely linked to organizations' resource dependencies. In contrast with the sense of empowerment reported by CAMP members, refugees volunteering with VOL described traumatic experiences as 'middle men' carrying messages between the Home Office and 'clients', and perceived by other refugees as holding far more power than they did. CAMP's format of more regular General Meetings allowed the committee to play a more purely administrative function. This format was particularly suited to CAMP due to the organization's reliance on mobilizations of its membership, which in turn called for strong 
accountability to retain members' commitment. CAMP's internationalism and prioritization of grassroots mobilizations also helped shift power within the organization toward refugee members, whose knowledge of countries and struggles outside Britain was highly valued to inform international understandings, as were their connections to wider refugee communities, discussed below. This is different from many other alliances between 'native' organizations and migrants, which Nicholls (2011, pp. 5-6) suggests often tend to distribute power toward native organizations because they possess the most valued 'discourse and legal expertise', and because in the 'national' context narrowly conceived, any 'activist capital' possessed by migrants is not easily transferable.

\section{Action: Community mobilizing}

Butcher (2007) outlines the CCP's principles of action, including: conscientization, described as 'consciousness through action'; empowerment, described as 'the collective mobilisation of power to shape public decisions, influence agendas, and effectively challenge hegemonic ideologies and oppressive discourses'; and collective action, encompassing motivation, skills and capacities; together leading to transformational change and emancipation of individuals and groups (pp. 57-8). CAMP's activities developed within a similar framework, prioritising the potential for members' collective action as the organization's greatest strength. As one member said:

I think one person alone cannot change things ... solidarity is very important ... I see myself ... playing a part where I can ... many people ... need to play their part so that change can be seen.

CAMP's ability to mobilize was strengthened by non-political, 'broadbased' networks, formal and informal, in which members were embedded, as has been found in other migrants' rights mobilizations (Bunyan 2010, p. 115; Però 2008, p. 83). The 'community' mobilized by CAMP was diverse, and different members were uniquely placed to mobilize different groups, including communities based around a shared country of origin (sometimes including non-refugees), geographical neighbourhoods, religious congregations, and activist and trade union networks. Specific practices within this framework included informal contacts with friends, street stalls, public meetings, press releases and 
media interviews, demonstrations, pickets, marches, door-knocking, and distribution of leaflets and a newsletter.

Banks (2007, p. 86) suggests 'campaigning, protests, leaflets and media coverage are one way of starting a process of deliberative civic action by making the public and others aware of the asylum seekers' perspectives and the plight that they face'. One member explained the priority CAMP gave to raising awareness in order to inform action:

Most of the British citizens, they don't know what goes on with asylum case[s] ... when they [immigration police] dawn-raided my house, [a neighbor] told her granddaughter what happened and the granddaughter was saying does this happen in Britain? ... where somebody's door could be broken and things like that ... there needs to be [an organization] enlightening people about what's going on, and once people see ... they can ... act Another member described CAMP's distinctiveness compared to organizations focused on providing services:

there are many, many charities here, I'm not saying they're not doing good work ... because when people are destitute ... they are giving money to them, they are giving [a] parcel of food, but ... when someone has been snatched, or the immigration [police] come and they want to deport [you] ... CAMP ... is helping many, many people, and since l've started going there I know that still I'm an asylum seeker but I'm a human being and l've got my rights ... if l've got problems I can ring them at any time and they will be there and they will come and try to help me. But not just help me, they are trying also to explain to people who asylum seekers are ... and they are trying even to challenge [government] policies.

Empowerment was achieved by CAMP through cycles of action, reflection, and discussion, as Takhar (2011) argues: 'being "empowered" ... is not simply a case of placing trust in another person to act as an advocate, but to take action, thereby generating even more power' (p. 347). This was described by a member of CAMP:

[A CAMP member was taken into immigration custody] and CAMP, we did something big ... we went to the [local government offices] ... we did everything that we could, and she came out, that was ... a very good thing for us ... to see that we also have some power, so if we want something we can get it 
The approach described above contrasts with organizations supporting asylum rights through service provision, professional lobbying, casework, or research. The other organizations in my study provided valuable services, including: support in navigating legal processes, befriending and social activities (VOL); hardship funding and help filling in forms (CHUR); community social events and one to one support with the immigration system and service providers (COM). CAMP's approach was more overtly political, aiming to build an independent movement strong enough to force changes in government policy. Banks (2007, pp. 85-6) conceptualizes this as a combination of elements of 'power with', in terms of CAMP's internal organization, and 'power over' in its external actions. There is an underlying assumption in the CCP model, that people at all levels of society, including politicians and others in positions of power and privilege, can cooperate together to transform society and liberate oppressed groups and individuals (Butcher 2007, pp. 66-72). By contrast, in CAMP the predominant view, based on shared experience and reflection, was that the British state and those managing it were actively hostile to refugees, and approaches to the state followed from this, emphasizing self-reliance, autonomy, and resistance rather than partnership.

\section{Resources: Community fundraising and members' resources}

CAMP considered resource independence and freedom from political constraints associated with charity registration as essential to independently represent refugees' interests (similar to LAWA, Però 2008, p. 83). CAMP ran on a minimal budget, the main sources of income being a small number of monthly standing orders from individual supporters, sales of campaign literature and badges, and musical benefit events. This provided funds for travel expenses, which many CAMP members needed to attend the group's activities, and for the hire of a church for monthly General Meetings, given at a discounted rate. The organization found the rest of the resources it needed through members' networks. For example, for much of the organization's existence a meeting room was provided at no cost in the back room of a charity bookshop and the printing of leaflets and newsletters was donated by an affiliated organization.

At several points between 2006 and 2010, there were pressures from sections of the membership to register as a charity and apply for 
grant funding. This was often linked to a belief that this would enable CAMP to pay for immigration solicitors, reflecting the pressures of the asylum system to individualize each applicant's 'case'. Each time this was discussed the majority of CAMP's membership opted to retain financial independence. Interviews I conducted and my own experience suggest this was informed, to varying degrees for different members, by an understanding of a basic contradiction between the interests of refugees and the interests represented by the British state, and observations of the practical limitations faced by many funded organizations, particularly those most closely linked to the state. A CAMP member who had also volunteered with VOL explained:

CAMP is strong, because sometimes you have to challenge the government ... [VOL] is partially funded by the government, so that means ... you can never challenge, otherwise you will be out. So when I'm doing [voluntary] work with VOL it's just to help people [find out] how to get financial support ... If I want someone to fight for his rights to stay in this country I will lead this person to ... CAMP

Figure 2 provides an overview of how the key features of the IARM fit together according to the dimensions in Figure 1. 
Figure 2: Features of the IARM

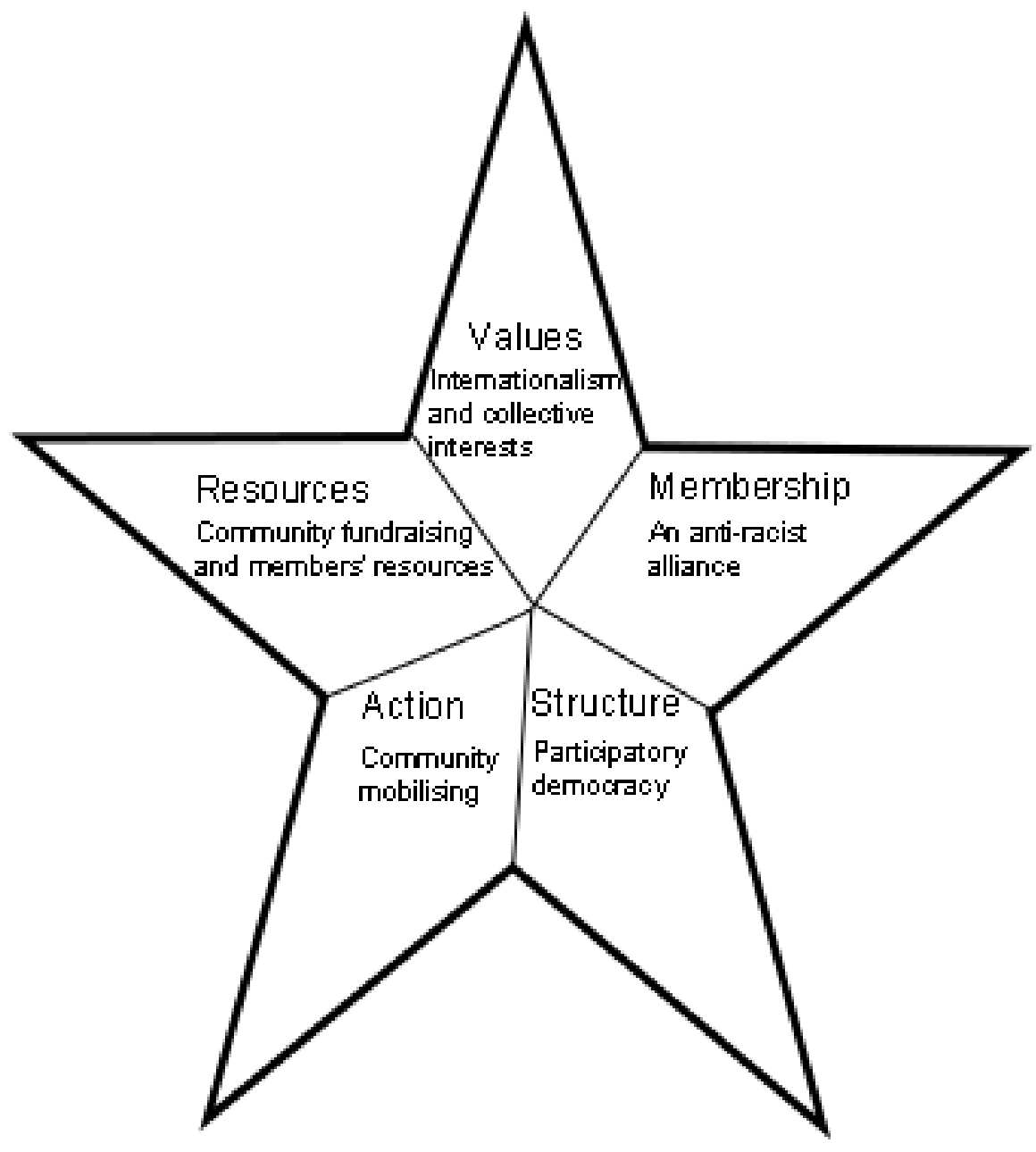

\section{CAMP in historical perspective}

CAMP emerged under conditions that need to be taken into account when considering the transferability of the IARM:

- The severity of hardships most refugees without status were facing (Prior 2006; Lewis 2009), coupled with the indefinite and often long wait for cases to be decided (Hynes 2009), radicalized refugees and their supporters because it fostered few hopes that the government might change its policies, except under extreme pressure.

- The numbers facing the same problems as refugees without status (British Red Cross 2010; Griffiths et al. 2005: p. 38), which both created grounds for a collective consciousness of specific 
oppressive policies and left individual anti-deportation campaigns (e.g. Ford 1998; Welford 1988) increasingly inadequate. The conditions above, which made CAMP possible, were augmented by two factors discussed earlier in this paper, which pushed people's responses in a particular direction and contributed to the rapid growth of support for CAMP:

- Expectations that social professionals should police refugees' access to services radicalized some workers, because it profoundly contradicted their personal and professional values. CAMP's founding members included such individuals, who felt frustrated with the limitations of their paid roles in other organizations and so contributed to CAMP in their spare time.

- The lack of preparation in dispersal areas resulted in a lack of structures to channel refugees' complaints into less confrontational approaches. In the city where CAMP was based, 'race relations' networks which had been set up in the 1960s to mediate relationships of predominantly South Asian communities with the state were largely ineffective at relating to refugees arriving from countries in Africa and the Middle East (Vickers 2012).

Within this context, the political intervention by a small group of activists to initiate CAMP acted as a catalyst. Figure 3 summarizes these contextual conditions. 
Figure 3: Enabling conditions for the IARM

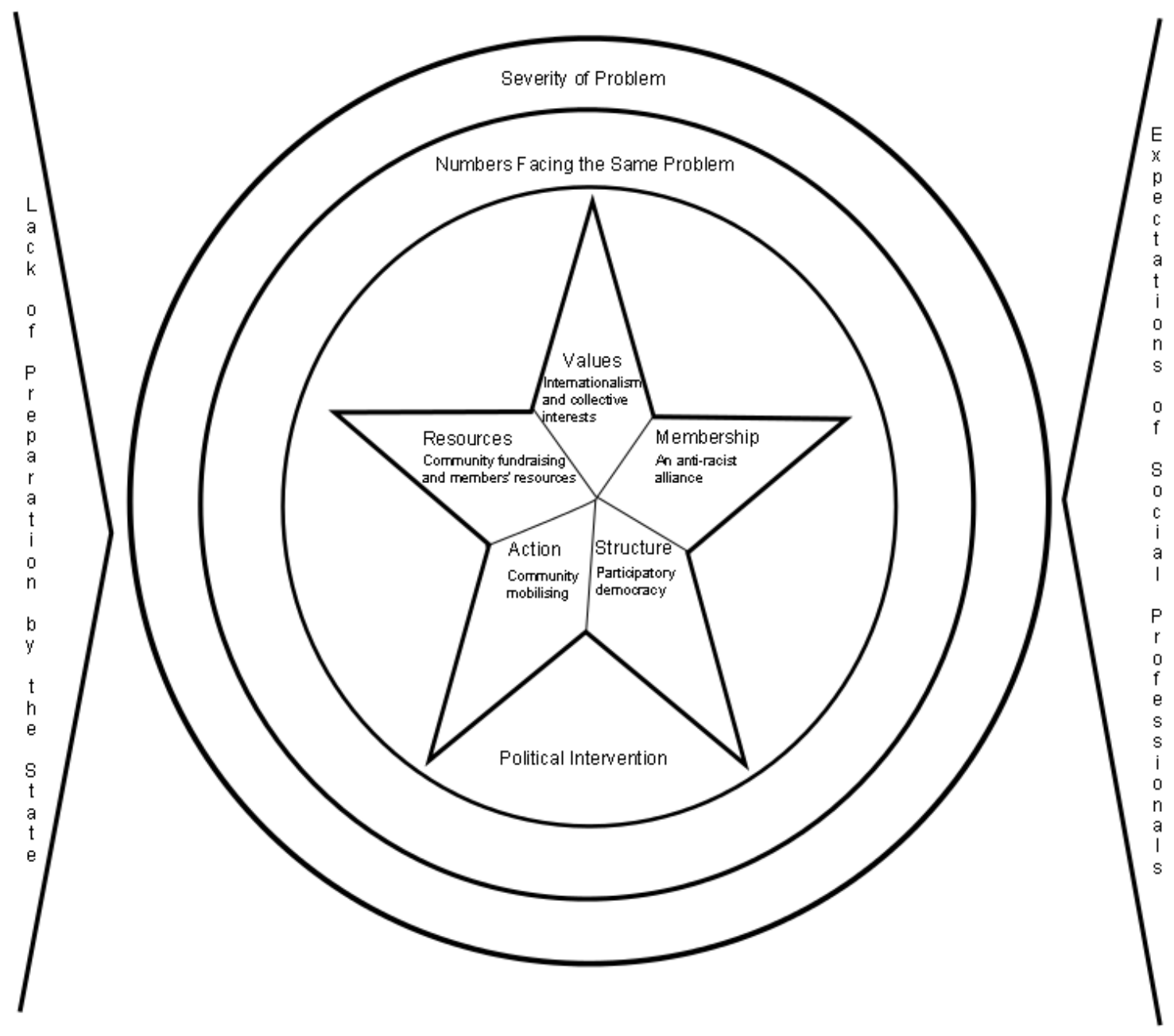

Changes to these conditions would eventually make CAMP's ways of operating described in this paper no longer viable. In 2007 a 'legacy exercise' began to clear the backlog of undecided asylum cases, with many being granted some form of status, and a continuing expansion of immigration detention facilities meant more refugees without status could be housed away from contact with non-refugees (Hynes 2009). These factors contributed to a decline in communitybased asylum rights mobilizations nationally, whilst inside immigration detention centres hunger strikes, break-outs and other forms of resistance continued, largely isolated from outside support (Jameson 2010). As a result many existing CAMP members either secured status or were deported. Those who secured status were faced with a new set of priorities and challenges, including the need to find work and housing, 
in some cases coupled with intense emotional relief/exhaustion, and some left the city for other parts of Britain. Changes to the dispersal system in 2007 and changes in asylum housing providers in 2010 further reduced the numbers of refugees without status living in the city where CAMP was based. These changed conditions inevitably affected CAMP, and by 2010 attendance at meetings had fallen considerably. Remaining members attempted to reorient CAMP toward wider antiracist issues, mounting several campaigns against individual instances of racial harassment, police racism, and racism in social services. Yet faced with a greater diversity of issues between individuals, and in the absence of significant wider movements on these issues, these campaigns were limited in scale and lacked the collective character of CAMP's earlier period.

\section{Conclusion}

This paper has presented a model for opposing government policies that are detrimental to refugees, through building alliances independent of the state, based on shared political values. The construction of a model, based on a particular configuration of values, membership, structure, action and resources, 'makes sense' of what distinguished CAMP from other asylum rights organizations in the same period. In particular, the model explains what enabled CAMP to defend refugees' interests in situations where other organizations could not, and to avoid becoming embroiled in attempts to make refugees accept and adapt to a deeply oppressive situation.

The combination of multiple sources enhances the model's robustness, including organizational literature and interviews as part of the 2007-2010 study, reflections on my personal experiences as a participant, and a chapter written by another author (Banks 2007). Comparisons with the CCP have situated the IARM within wider traditions of community organising, and the empirical data has enabled the paper to make a further contribution based on the specific conditions facing refugees in England, which foreground questions of racism and relationships with the state, as the principle arbiter of asylum rights within its borders.

The IARM has relevance to other groups whose conditions of life are made intolerable by the state. It emphasizes the importance of objective conditions which create a potential for collective resistance but 
also the importance of an organized intervention to realize this potential, by asserting claims based on political principles, in this case internationalist values which challenge nationalist state discourses (Chimienti 2011 discusses similar conjunctions of objective and subjective factors). Consideration of whether such a combination of conditions are present can inform the transfer of the model to other contexts. With wider relevance, the IARM also demonstrates that diverse alliances, united by political commitment, can draw together the resources necessary for sustained grassroots activity, without the need for state funding. The IARM is less suited to meeting immediate service needs, and therefore benefits from the coexistence of other types of organization, which may have different kinds of resource needs. In a context where Craig (2011, pp. 383-3) suggests funding cuts across the wider BME third sector could force a return to small self-help groups and campaigning organizations, such a model is likely to become increasingly relevant. 


\section{Notes}

${ }^{1}$ Due to the stigmatisation associated with the term 'asylum seeker', I use 'refugee' to encompass everyone who seeks refuge (as does Williams 2006), and where relevant I indicate whether I refer to refugees with or without 'status', in the sense of permission from the state to remain in Britain and enjoy the same formal rights as citizens.

${ }^{2}$ For a more detailed discussion see Vickers (2012).

${ }^{3}$ Where I use the term 'black' in this paper I do so in its political sense (Penketh 2000, p. v).

${ }^{4}$ Some solicitors also expressed this fear, but there was no evidence of any refugees' involvement in CAMP negatively affecting their asylum claim. Indeed, the proportion of members who secured status was well above the national average, although other factors might have contributed to this. 


\section{References}

AHMAD, WAQAR I. U. and ATKIN, KARL 1996 'Race' and Community Care, Buckingham: Open University Press

ANDERSON, BRIDGET 2010 'Mobilizing migrants, making citizens: migrant domestic workers as political agents', Ethnic and Racial Studies, vol. 33, no. 1, pp. 60-74

BAILEY, OLGA G. 2012 'Migrant African women: tales of agency and belonging', Ethnic and Racial Studies, vol. 35, no. 5, pp. 850-67

BANKS, SARAH 2007 'Working in and with community groups and organisations: processes and practices', in Hugh Butcher, et al. (eds), Critical Community Practice, Bristol: Policy Press

BID 2009 Out of Sight, Out of Mind: Experiences of Immigration Detention in the UK, London: Bail for Immigration Detainees

BRISKMAN, LINDA and CEMLYN, SARAH 2005 'Reclaiming humanity for asylum-seekers: a social work response', International Social Work, vol. 48, no. 6, pp. 714-24

BRITISH RED CROSS 2010 Not Gone, But Forgotten: The Urgent Need for a More Humane Asylum System, London: Red Cross

BUNYAN, PAUL 2010 'Broad-based organizing in the UK: reasserting the centrality of political activity in community development', Community Development Journal, vol. 45, no. 1, pp. 111-27

BUTCHER, HUGH 2007 'Towards a model of critical community practice', in Hugh Butcher, et al. (eds), Critical Community Practice, Bristol: Policy Press

BUTCHER, HUGH, et al. 2007 Critical Community Practice, Bristol: Policy Press

CHIMIENTI, MILENA 2011 'Mobilization of irregular migrants in Europe: a comparative analysis', Ethnic and Racial Studies, vol. 34, no. 8, pp. $1338-56$

CHINWEIZU, CHARLES and JAMESON, NICKI 2008 'Immigration and the reserve army of labour in Britain', Fight Racism! Fight Imperialism!, no. 201 February / March

CRAIG, GARY 2007 'Cunning, unprincipled, loathsome': the racist tail wags the welfare dog', Journal of Social Policy, vol. 36, no. 4, pp. 605-23

--- 2011 'Forward to the past: can the UK black and minority ethnic third sector survive?', Voluntary Sector Review, vol. 2, no. 3, pp. 36789 
ESTERHUIZEN, LEA 2004 Doing Case Studies for the Refugee Sector: A DIY Handbook for Agencies and Practitioners, London: ICAR EVELYN OLDFIELD UNIT 2004 Refugee Volunteering: Integration in Action. Report of a National Conference, London: Evelyn Oldfield

FORD, COREENA 1998 'Deportation flight switch', The Journal, 30 June. Newcastle

GRAMSCI, ANTONIO [1929-1935] 1982 Selections from the Prison Notebooks, London: Lawrence and Wishart

GRIFFITHS, DAVID, SIGONA, NANDO and ZETTER, ROGER 2005 Refugee Community Organisations and Dispersal: Networks, Resources and Social Capital, Bristol: The Policy Press

HAYES, DEBRA 2005 'Social work with asylum seekers and others subject to immigration control', in Robert Adams, Lena Dominelli and Malcolm Payne (eds), Social Work Futures: Crossing Boundaries, Transforming Practice, Basingstoke: Palgrave MacMillan

HENDERSON, PAUL 2007 'Introduction', in Hugh Butcher, et al. (eds), Critical Community Practice, Bristol: Policy Press

HEWITT, ROGER L. 2002 Asylum-seeker Dispersal and Community Relations: An Analysis of Developmental Strategies, London: Centre for Urban and Community Research, Goldsmiths College HILL COLLINS, PATRICIA 1990 'Defining black feminist thought', in Patricia Hill Collins (ed.), Black Feminist Thought: Knowledge, Consciousness, and the Politics of Empowerment, New York: Routledge

HIRSH, ELIZABETH and OLSON, GARY A. 1995 'Starting from marginalized lives: a conversation with Sandra Harding', JAC, vol. 15, no.2, pp. 193-225

HOME OFFICE 2010 'Control of Immigration: Quarterly Statistical Summary, United Kingdom January-March 2010'. London HUMPHRIES, BETH 2004 'An unacceptable role for social work: implementing immigration policy', British Journal of Social Work, vol. 34, no. 1, pp. 93-107

HYNES, PATRICIA 2009 'Contemporary compulsory dispersal and the absence of space for the restoration of trust', Journal of Refugee Studies, vol. 22, no. 1, pp. 97-121 
JAMESON, NICKI 2010 'Close Yarl's Wood! Close Harmondsworth! Close all immigration prisons!', Fight Racism! Fight Imperialism!, no. 214 April / May

KUNDNANI, ARUN 2007 The End of Tolerance: Racism in 21st Century Britain, London: Pluto Press

LEDWITH, MARGARET and ASGILL, PAULA 2000 'Critical alliance: black and white women working together for social justice', Community Development Journal, vol. 35, no. 3, pp. 290-99

LENTIN, ALANA 2004 Racism and Anti-Racism in Europe, London: Pluto Press

--- and TITLEY, GAVIN 2011 The Crises of Multiculturalism: Racism in a Neoliberal Age, London: Zed Books

LEWIS, HANNAH 2009 Still Destitute: A Worsening Problem for Refused Asylum Seekers, York: Joseph Rowntree Charitable Trust

MARX, KARL and ENGELS, FREDERICK [1845] 1991 The German Ideology, London: Lawrence Wishart

MORRIS, LYDIA 2007 'New Labour's community of rights: welfare, immigration and asylum', Journal of Social Policy, vol. 36, no. 1, pp. 39-57

NICHOLLS, WALTER J. 2011 'Fragmenting citizenship: dynamics of cooperation and conflict in France's immigrant rights movement', Ethnic and Racial Studies, November 2011, DOI:

10.1080/01419870.2011.626055

PENKETH, LAURA 2000 Tackling Institutional Racism: Anti-racist Policies and Social Work Education and Training, Bristol: Policy Press

PERÒ, DAVIDE 2008 'Political engagement of Latin Americans in the UK: Issues, strategies, and the public debate', Focaal: European Journal of Anthropology, vol. 51, pp. 73-90

PRIOR, JULIAN 2006 Destitute and Desperate: A Report on the Numbers of 'Failed' Asylum Seekers in Newcastle upon Tyne and the Services Available to Them, Newcastle: Open Door

SALES, ROSEMARY 2002 'The deserving and the undeserving? refugees, asylum seekers and welfare in Britain', Critical Social Policy, vol. 22, no. 3, pp. 456-78

SCHUSTER, LIZA 2002 'Asylum and the lessons of history', Race and Class, vol. 44, no. 2, pp. 40-56 
SHUKRA, KALBIR 1995 'From black power to black perspectives', Youth and Policy, no. 49, pp. 6-18

SILVERMAN, STEPHANIE J. 2011 Immigration Detention in the UK, Oxford: The Migration Observatory

TAKHAR, SHAMINDER 2011 'The construction of political agency: South Asian women and political activism', Community Development Journal, vol. 46, no. 3, pp. 341-50

VICKERS, TOM 2012 Refugees, Capitalism and the British State: Implications for Social Workers, Volunteers and Activists, London: Ashgate

WELFORD, GARY 1988 'Father wins battle to stay with his family', The Journal, 17 November. Newcastle

WILLIAMS, LUCY 2006 'Social networks of refugees in the United Kingdom: tradition, tactics and new community spaces', Ethnic and Migration Studies, vol. 32, no. 5, pp. 865-79

WLRI 2005 Women Refugees: From Volunteers to Employees, London: Working Lives Research Institute

YIN, ROBERT K. 2003 Case Study Research: Design and Methods, 3rd edn, Thousand Oaks, CA: Sage Publications

YÚDICE, GEORGE 2003 The Expediency of Culture: Uses of Culture in the Global Era. Durham, NC: Duke University Press

TOM VICKERS is Senior Research Assistant in the School of Arts \& Social Sciences at Northumbria University.

ADDRESS: Squires Building 001, SASS, Northumbria University, Newcastle, NE1 8ST, UK. Email: tom.vickers@northumbria.ac.uk 